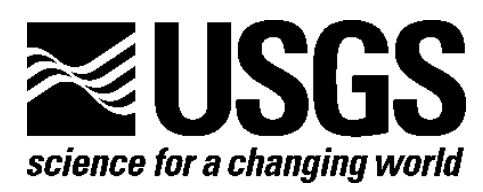

\title{
Publications of the Volcano Hazards Program 2008
}

By Manuel Nathenson

Open-File Report 2010-1052

U.S. Department of the Interior

U.S. Geological Survey 


\section{U.S. Department of the Interior \\ KEN SALAZAR, Secretary}

\section{U.S. Geological Survey \\ Marcia K. McNutt, Director}

U.S. Geological Survey, Reston, Virginia: 2010

For product and ordering information:

World Wide Web: http://www.usgs.gov/pubprod

Telephone: 1-888-ASK-USGS

For more information on the USGS-the Federal source for science about the Earth,

its natural and living resources, natural hazards, and the environment:

World Wide Web: http://www.usgs.gov

Telephone: 1-888-ASK-USGS

Suggested citation:

Nathenson, Manuel, 2010, Publications of the Volcano Hazards Program 2008: U.S. Geological Survey

Open-File Report 2010-1052, 14 p.

Any use of trade, product, or firm names is for descriptive purposes only and does not imply endorsement by the U.S. Government.

Although this report is in the public domain, permission must be secured from the individual copyright owners to reproduce any copyrighted material contained within this report. 


\title{
Publications of the Volcano Hazards Program 2008
}

\author{
By Manuel Nathenson
}

The Volcano Hazards Program of the U.S. Geological Survey (USGS) is part of the Geologic Hazards Assessments subactivity as funded by Congressional appropriation. Investigations are carried out in the Geology and Hydrology Disciplines of the USGS and with cooperators at the Alaska Division of Geological and Geophysical Surveys, University of Alaska Fairbanks Geophysical Institute, University of Hawaii Manoa and Hilo, University of Utah, and University of Washington Geophysics Program. This report lists publications from all these institutions.

This report contains only published papers and maps; numerous abstracts produced for presentations at scientific meetings have not been included. Publications are included based on date of publication with no attempt to assign them to Fiscal Year. 


\section{Volcano Hazards Bibliography 2008}

Alaska Volcano Observatory, Alaska Division of Homeland Security and Emergency Management, Federal Aviation Administration, National Weather Service, U.S. Air Force, U.S. Coast Guard, and Alaska Department of Environmental Conservation, 2008, Alaska interagency operating plan for volcanic ash episodes, 52 p., available at http://avo.alaska.edu/pdfs/cit3996_2008.pdf.

Ancey, C., Iverson, R.M., Rentschler, M., and Denlinger, R.P., 2008, An exact solution for ideal dam-break floods on steep slopes: Water Resources Research, v. 44, W01430, doi:10.1029/2007WR006353, 10 p.

Arciniega-Ceballos, Alejandra, Chouet, Bernard, Dawson, Phillip, and Asch, Guenter, 2008, Broadband seismic measurements of degassing activity associated with lava effusion at Popocatépetl Volcano, Mexico, in Delgado Granados, H., De la Cruz Reyna, S., and Tilling, R.I., eds., The 1994-present eruption of Popocatépetl; background, current activity, and impacts: Journal of Volcanology and Geothermal Research, v. 170, p. 12-23.

Bacon, C.R., 2008, Geologic map of Mount Mazama and Crater Lake Caldera, Oregon: U.S. Geological Survey Scientific Investigations Map 2832, 45 p., 4 plates, scale 1:24,000, available at http://pubs.usgs.gov/sim/2832/.

Ball, J.W., McCleskey, R.B., Nordstrom, D.K., and Holloway, J.M., 2008, Water-chemistry data for selected springs, geysers, and streams in Yellowstone National Park, Wyoming, 20032005: U.S. Geological Survey Open-File Report 2006-1339, 137 p., available at http://pubs.usgs.gov/of/2006/1339/.

Battaglia, Maurizio, Dzurisin, Daniel, Langbein, John, Svarc, Jerry, and Hill, D.P., 2008, Converting NAD83 GPS heights into NAVD88 elevations with LVGEOID, a hybrid geoid height model for the Long Valley volcanic region, California: U.S. Geological Survey Scientific Investigations Report 2007-5255, 32 p., available at http://pubs.usgs.gov/sir/2007/5255/.

Battaglia, Maurizio, Gottsmann, Joachim, Carbone, Daniele, and Fernández, José, 2008, 4D volcano gravimetry: Geophysics, v. 73, no. 6, doi:10.1190/1.2977792, p. WA3-WA18.

Begét, James, Gardner, Cynthia, and Davis, Kathleen, 2008, Volcanic tsunamis and prehistoric cultural transitions in Cook Inlet, Alaska: Journal of Volcanology and Geothermal Research, v. 176, p. 377-386.

Bergfeld, Deborah, Evans, W.C., McGee, K.A., and Spicer, K.R., 2008, Pre- and post-eruptive investigations of gas and water samples from Mount St. Helens, Washington, 2002 to 2005 , chap. 25 of Sherrod, D.R., Scott, W.E., and Stauffer, P.H., eds., A volcano rekindled; the renewed eruption of Mount St. Helens, 2004-2006: U.S. Geological Survey Professional Paper 1750, p. 523-542, available at http://pubs.usgs.gov/pp/1750/.

Brooks, B.A., Foster, James, Sandwell, David, Wolfe, C.J., Okubo, Paul, Poland, Michael, and Myer, David, 2008, Magmatically triggered slow slip at Kilauea Volcano, Hawaii: Science, v. 321, p. 1177.

Cashman, K.V., Thornber, C.R., and Pallister, J.S., 2008, From dome to dust-Shallow crystallization and fragmentation of conduit magma during the 2004-2006 dome extrusion of Mount St. Helens, Washington, chap. 19 of Sherrod, D.R., Scott, W.E., and Stauffer, P.H., eds., A volcano rekindled; the renewed eruption of Mount St. Helens, 2004-2006: U.S. 
Geological Survey Professional Paper 1750, p. 387-413, available at http://pubs.usgs.gov/pp/1750/.

Casu, F., Solaro, G., Tizzani, P., Poland, M., Miklius, A., Sansosti, E., and Lanari, R., 2008, Surface deformation analysis of the Mauna Loa and Kīlauea volcanoes, Hawai ${ }^{i} i$, based on InSAR displacement time series: Second workshop on Use of Remote Sensing Techniques (USEReST) for Monitoring Volcanoes and Seismogenic Areas, November 11-14, 2008, IEEE Conference Publications Program, doi:10.1109/USEREST.2008.4740368, 4 p.

Cesca, S., Battaglia, J., Dahm, T., Tessmer, E., Heimann, S., and Okubo, P., 2008, Effects of topography and crustal heterogeneities on the source estimation of LP event at Kilauea volcano: Geophysical Journal International, v. 172, p. 1219-1236.

Chouet, Bernard, Dawson, Phillip, and Martini, Marcello, 2008, Shallow-conduit dynamics at Stromboli Volcano, Italy, imaged from waveform inversions, in Lane, S.J., and Gilbert, J.S., eds., Fluid motions in volcanic conduits; a source of seismic and acoustic signals: Geological Society of London Special Publication 307, p. 57-84.

Chouet, Bernard, Dawson, Phillip, and Martini, Marcello, 2008, Upper conduit structure and explosion dynamics at Stromboli, in Calvari, Sonia, Inguaggiato, Salvatore, Puglisi, Giuseppe, Ripepe, Maurizio, and Rosi, Mauro, eds., The Stromboli Volcano, an integrated study of the 2002-2003 eruption: American Geophysical Union Geophysical Monograph 182, p. 81-92.

Clynne, M.A., Calvert, A.T., Wolfe, E.W., Evarts, R.C., Fleck, R.J., and Lanphere, M.A., 2008, The Pleistocene eruptive history of Mount St. Helens, Washington, from 300,000 to 12,800 years before present, chap. 28 of Sherrod, D.R., Scott, W.E., and Stauffer, P.H., eds., A volcano rekindled; the renewed eruption of Mount St. Helens, 2004-2006: U.S. Geological Survey Professional Paper 1750, p. 593-627, available at http://pubs.usgs.gov/pp/1750/. Clynne, M.A., Christiansen, R.L., Trimble, D.A., and McGeehin, J.P., 2008, Radiocarbon dates from volcanic deposits of the Chaos Crags and Cinder Cone eruptive sequences and other deposits, Lassen Volcanic National Park and vicinity, California: U.S. Geological Survey Open-file Report 02-290, 18 p., available at http://pubs.usgs.gov/of/2002/of02-290/.

Clynne, M.A., Muffler, L.J.P., Siems, D.F., Taggart, J.E., Jr., and Bruggman, Peggy, 2008, Major and EDXRF trace element chemical analyses of volcanic rocks from Lassen Volcanic National Park and vicinity: U.S. Geological Survey Open-File Report 2008-1091, 11 p., data table, available at http://pubs.usgs.gov/of/2008/1091/.

Coombs, M.L., McGimsey, R.G., and Browne, B.L., 2008, Preliminary volcano-hazard assessment for Gareloi volcano, Gareloi Island, Alaska: U.S. Geological Survey Scientific Investigations Report 2008-5159, 32 p., 1 plate, available at http://pubs.usgs.gov/sir/2008/5159/.

Decker, Robert, Okamura, Arnold, Miklius, Asta, and Poland, Michael, 2008, Evolution of deformation studies on active Hawaiian volcanoes: U.S. Geological Survey Scientific Investigations Report 2008-5090, 23 p., available at http://pubs.usgs.gov/sir/2008/5090/.

De la Cruz Reyna, Servando, and Tilling, R.I., 2008, Scientific and public responses to the ongoing volcanic crisis at Popocatépetl Volcano, Mexico-Importance of an effective hazardswarning system, in Delgado Granados, H., De la Cruz Reyna, S., and Tilling, R.I., eds., The 1994-present eruption of Popocatépetl; background, current activity, and impacts: Journal of Volcanology and Geothermal Research, v. 170, p. 121-134.

Delgado Granados, H., De la Cruz Reyna, S., and Tilling, R.I., eds., 2008, The 1994-present eruption of Popocatépetl; background, current activity, and impacts: Journal of Volcanology and Geothermal Research, v. 170, p. 1-134. 
Delgado Granados, H., De la Cruz Reyna, S, and Tilling, R.I., 2008, The 1994-present eruption of Popocatépetl volcano; background, current activity, and impacts, in Delgado Granados, H., De la Cruz Reyna, S., and Tilling, R.I., eds., The 1994-present eruption of Popocatépetl; background, current activity, and impacts: Journal of Volcanology and Geothermal Research, v. 170, p. 1-4.

Di Muro, Andrea, Pallister, John, Villemant, Benoit, Newhall, Chris, Semet, Michel, Martinez, Mylene, and Mariet, Clarisse, 2008, Pre-1991 sulfur transfer between mafic injections and dacite magma in the Mt. Pinatubo reservoir: Journal of Volcanology and Geothermal Research, v, 175, p. 517-540.

Dixon, J.P., Stihler, S.D., and Power, J.A., 2008, Catalog of earthquake hypocenters at Alaskan volcanoes; January 1 through December 31, 2007: U.S. Geological Survey Data Series 367, 82 p., data files, available at http://pubs.usgs.gov/ds/367/.

Dixon, J.P., Stihler, S.D., Power, J.A., and Searcy, Cheryl, 2008, Catalog of earthquake hypocenters at Alaskan volcanoes; January 1 through December 31, 2006: U.S. Geological Survey Data Series 326, 79 p., data files, available at http://pubs.usgs.gov/ds/326/.

Donnelly-Nolan, J.M., 2008, Chemical analyses of pre-Holocene rocks from Medicine Lake Volcano and vicinity, northern California: U.S. Geological Survey Open-File Report 20081094, 9 p., data file, available at http://pubs.usgs.gov/of/2008/1094/.

Donnelly-Nolan, J.M., Grove, T.L., Lanphere, M.A., Champion, D.E., and Ramsey, D.W., 2008, Eruptive history and tectonic setting of Medicine Lake Volcano, a large rear-arc volcano in the southern Cascades: Journal of Volcanology and Geothermal Research, v. 177, p. 313-328.

Driedger, C.L., Neal, C.A., Knappenberger, T.H., Needham, D.H., Harper, R.B., and Steele, W.P., 2008, Hazard information management during the autumn 2004 reawakening of Mount St. Helens volcano, Washington, chap. 24 of Sherrod, D.R., Scott, W.E., and Stauffer, P.H., eds., A volcano rekindled; the renewed eruption of Mount St. Helens, 2004-2006: U.S.

Geological Survey Professional Paper 1750, p. 505-519, available at http://pubs.usgs.gov/pp/1750/.

Driedger, C.L., and Scott, W.E., 2008, Mount Rainier-Living safely with a volcano in your backyard: U.S. Geological Survey Fact Sheet 2008-3062, 4 p., available at http://pubs.usgs.gov/fs/2008/3062/.

Dzurisin, Daniel, Lisowski, Michael, Poland, M.P., Sherrod, D.R., and LaHusen, R.G., 2008, Constraints and conundrums resulting from ground-deformation measurements made during the 2004-2005 dome-building eruption of Mount St. Helens, Washington, chap. 14 of Sherrod, D.R., Scott, W.E., and Stauffer, P.H., eds., A volcano rekindled; the renewed eruption of Mount St. Helens, 2004-2006: U.S. Geological Survey Professional Paper 1750, p. 281-300, available at http://pubs.usgs.gov/pp/1750/.

Edmonds, Marie, McGee, K.A., and Doukas, M.P., 2008, Chlorine degassing during the lava dome-building eruption of Mount St. Helens, 2004-2005, chap. 27 of Sherrod, D.R., Scott, W.E., and Stauffer, P.H., eds., A volcano rekindled; the renewed eruption of Mount St. Helens, 2004-2006: U.S. Geological Survey Professional Paper 1750, p. 573-589, available at http://pubs.usgs.gov/pp/1750/.

Evarts, R.C., and O'Connor, J.E., 2008, Geologic map of the Camas Quadrangle, Clark County, Washington, and Multnomah County, Oregon: U.S. Geological Survey Scientific Investigations Map 3017, 32 p., 1 plate, scale 1:24,000, available at http://pubs.usgs.gov/sim/3017/. 
Fedele, Lorenzo, Scarpati, Claudio, Lanphere, Marvin, Melluso, Leone, Morra, Vincenzo, Perrotta, Annamaria, and Ricci, Gennaro, 2008, The Breccia Museo formation, Campi Flegrei, southern Italy; geochronology, chemostratigraphy and relationship with the Campanian Ignimbrite eruption: Bulletin of Volcanology, v. 70, p. 1189-1219.

Feeley, T.C., Clynne, M.A., Winer, G.S., and Grice, W.C., 2008, Oxygen isotope geochemistry of the Lassen volcanic center, California; resolving crustal and mantle contributions to continental arc magmatism: Journal of Petrology, v. 49, p. 971-997.

Fierstein, Judy, and Hildreth, Wes, 2008, Kaguyak dome field and its Holocene caldera, Alaska Peninsula: Journal of Volcanology and Geothermal Research, v. 177, p. 340-366.

Finney, Benjamin, Turner, Simon, Hawkesworth, Chris, Larsen, Jessica, Nye, Chris, George, Rhiannon, Bindeman, Ilya, and Eichelberger, John, 2008, Magmatic differentiation at an island-arc caldera-Okmok Volcano, Aleutian Islands, Alaska: Journal of Petrology, v. 49, p. 857-884.

Flynn, Kathryn, Graham Wall, Brita, White, D.E., Hutchinson, R.A., Keith, T.E.C., Clor, Laura, and Robinson, J.E., 2008, Database of the geology and thermal activity of Norris Geyser Basin, Yellowstone National Park: U.S. Geological Survey Data Series 324, available at http://pubs.usgs.gov/ds/324/.

Fournier, R.O., and Moore, M.M., 2008, Taming of a wild research well in Yellowstone National Park during November 1992: U.S. Geological Survey Open-File Report 2008-1014, MP4 video, available at http://pubs.usgs.gov/of/2008/1014/.

Fournier, Thomas, and Freymueller, Jeff, 2008, Inflation detected at Mount Veniaminof, Alaska, with campaign GPS: Geophysical Research Letters, v. 35, L20306, doi:10.1029/2008GL035503, 5 p.

Fournier, T.J., 2008, Analysis and interpretation of volcano deformation in Alaska-Studies from Okmok and Mt. Veniaminof volcanoes: University of Alaska Fairbanks Ph.D. dissertation, 134 p., available at http://avo.alaska.edu/pdfs/cit4516.pdf

Geist, D.J., Harpp, K.S., Naumann T.R., Poland, M.P., Chadwick, W.W., Hall, Minard, and Rader, Erika, 2008, The 2005 eruption of Sierra Negra volcano, Galápagos, Ecuador: Bulletin of Volcanology, v. 70, p. 655-673.

Gerlach, T.M., McGee, K.A., and Doukas, M.P., 2008, Emission rates of $\mathrm{CO}_{2}, \mathrm{SO}_{2}$, and $\mathrm{H}_{2} \mathrm{~S}$, scrubbing, and preeruption excess volatiles at Mount St. Helens, 2004-2005, chap. 26 of Sherrod, D.R., Scott, W.E., and Stauffer, P.H., eds., A volcano rekindled; the renewed eruption of Mount St. Helens, 2004-2006: U.S. Geological Survey Professional Paper 1750, p. 543-571, available at http://pubs.usgs.gov/pp/1750/.

Got, Jean-Luc, Monteiller, Vadim, Monteux, Julien, Hassani, Riad, and Okubo, Paul, 2008, Deformation and rupture of the oceanic crust may control growth of Hawaiian volcanoes: Nature, v. 451, no. 7177, p. 453-456.

Grant, G., Marr, J.D.G., Hill, C., Johnson, S., Campbell, K., Mohseni, O., Wallick, J.R., Lewis, S.L., O’Connor, J.E., Major, J.J., and Burkholder, B.K., 2008, Experimental and field observations of breach dynamics accompanying erosion of Marmot cofferdam, Sandy River, Oregon, in Babcock, R.W., and Walton, R., eds., Proceedings of the 2008 world environmental and water resources congress: Ahupua'a, Honolulu, Hawaii, May 12-16, 2008, American Society of Civil Engineers $10 \mathrm{p}$.

Gregg, C.E., Houghton, B.F., Paton, D., Swanson, D.A., Lachman, R., and Bonk, W.J., 2008, Hawaiian cultural influences on support for lava flow hazard mitigation measures during the January 1960 eruption of Kīlauea volcano, Kapoho, Hawai'i, in Gaillard, J.-C., and Dibben, 
C.J.L., eds., Volcanic risk perception and beyond: Journal of Volcanology and Geothermal Research, v. 172, p. 300-307.

Griswold, J.P., and Iverson, R.M., 2008, Mobility statistics and automated hazard mapping for debris flows and rock avalanches: U.S. Geological Survey Scientific Investigations Report 2007-5276, 59 p., available at http://pubs.usgs.gov/sir/2007/5276/.

Hager, S.A., Gerlach, T.M., and Wallace, P.J., 2008, Summit $\mathrm{CO}_{2}$ emission rates by the $\mathrm{CO}_{2} / \mathrm{SO}_{2}$ ratio method at Kìlauea Volcano, Hawai' $i$, during a period of sustained inflation: Journal of Volcanology and Geothermal Research, v. 177, p. 875-882.

Hartog, Renate, Gomberg, Joan, Moran, S.C., Wright, Amy, and Meagher, K.L., 2008, The 8 October $2006 \mathrm{M}_{\mathrm{d}} 4.5$ Cowlitz Chimneys earthquake in Mount Rainier National Park:

Seismological Research Letters, v. 79, p. 186-193.

Herriott, T.M., Sherrod, D.R., Pallister, J.S., and Vallance, J.W., 2008, Photogeologic maps of the 2004-2005 Mount St. Helens eruption, chap. 10 of Sherrod, D.R., Scott, W.E., and Stauffer, P.H., eds., A volcano rekindled; the renewed eruption of Mount St. Helens, 20042006: U.S. Geological Survey Professional Paper 1750, p. 209-224, available at http://pubs.usgs.gov/pp/1750/.

Hill, D.P., 2008, Dynamic stresses, Coulomb failure, and remote triggering: Bulletin of the Seismological Society of America, v. 98, p. 66-92.

Hoblitt, R.P., Orr, T.R., Castella, Frederic, and Cervelli, P.F., 2008, Remote-controlled pan, tilt, zoom cameras at Kìlauea and Mauna Loa Volcanoes, Hawai'i: U.S. Geological Survey Scientific Investigations Report SIR 2008-5129, 14 p. available at http://pubs.usgs.gov/sir/2008/5129/.

Hopson, C.A., 2008, Geologic map of Mount St. Helens, Washington prior to the 1980 eruption: U.S. Geological Survey Open-File Report 02-468, 2 sheets, scale 1:31,250, available at http://pubs.usgs.gov/of/2002/of02-468/.

Horton, S.P., Norris, R.D., and Moran, S.C., 2008, Broadband characteristics of earthquakes recorded during a dome-building eruption at Mount St. Helens, Washington, between October 2004 and May 2005, chap. 5 of Sherrod, D.R., Scott, W.E., and Stauffer, P.H., eds., A volcano rekindled; the renewed eruption of Mount St. Helens, 2004-2006: U.S. Geological Survey Professional Paper 1750, p. 97-110, available at http://pubs.usgs.gov/pp/1750/.

Huggel, C., Caplan-Auerbach, J., and Wessels, R., 2008, Recent extreme avalanches; triggered by climate change?: Eos Transactions American Geophysical Union, v. 89, p. 469-470.

Hurwitz, Shaul, Eagan, Sean, Heasler, Henry, and Lowenstern, J.B., 2007, revised 2008, River chemistry and solute flux in Yellowstone National Park: U.S. Geological Survey Data Series 278, version 2.0, available at http://pubs.usgs.gov/ds/2007/278/.

Hurwitz, Shaul , Kumar, Ashish, Taylor, Ralph , and Heasler, Henry, 2008, Climate-induced variations of geyser periodicity in Yellowstone National Park, USA: Geology, v. 36, p. 451454.

Ingebritsen, S.E., Hurwitz, S., and Brodsky, E., 2008, Note from the Hubbert Quorum: Geofluids, v. 8, p. 1-2.

Iverson, R.M., 2008, Dynamics of seismogenic volcanic extrusion resisted by a solid surface plug, Mount St. Helens, 2004-2005, chap. 21 of Sherrod, D.R., Scott, W.E., and Stauffer, P.H., eds., A volcano rekindled; the renewed eruption of Mount St. Helens, 2004-2006: U.S. Geological Survey Professional Paper 1750, p. 425-460, available at http://pubs.usgs.gov/pp/1750/. 
Iverson, R.M., 2008, Book review of Avalanche Dynamics by Shiva P. Pudasaini and Kolumban Hutter, 2007, Springer: Berlin-Heidelberg, 602 p.: Journal of Geology, v. 116, p. 103.

John, D.A., Sisson, T.W., Breit, G.N., Rye, R.O., and Vallance, J.W., 2008, Characteristics, extent and origin of hydrothermal alteration at Mount Rainier volcano, Cascades Arc, USA; implications for debris-flow hazards and mineral deposits: Journal of Volcanology and Geothermal Research, v. 175, p. 289-314.

Jonssón, Sigurjón, Chadwick, William, Poland, Michael, and Geist, Dennis, 2008, Deformation and stress-change modeling at Sierra Negra Volcano, Galapagos, from Envisat InSAR and GPS Observations: Proceedings of FRINGE 2007, Frascati, Italy, Nov. 26-30, 2007, ESA SP649, 5 p.

Kent, A.J.R., Rowe, M.C., Thornber, C.R., and Pallister , J.S., 2008, Trace element and Pb isotope composition of plagioclase from dome samples from the 2004-2005 eruption of Mount St. Helens, Washington, chap. 35 of Sherrod, D.R., Scott, W.E., and Stauffer, P.H., eds., A volcano rekindled; the renewed eruption of Mount St. Helens, 2004-2006: U.S. Geological Survey Professional Paper 1750, p. 809-826, available at http://pubs.usgs.gov/pp/1750/.

Klein, F.W., and Wright, T.L., 2008, Exponential decline of aftershocks of the M7.9 1868 great Kau earthquake, Hawaii, through the 20th century: Journal of Geophysical Research, v. 113, B09310, doi:10.1029/2007JB005411, 11 p.

Kusakabe, Minoru, Ohba, Takeshi, Issa, Yoshida, Yutaka, Satake, Hiroshi, Ohizumi, Tsuyoshi, Evans, W.C., Tanyileke, Gregory, and Kling, G.W., 2008, Evolution of $\mathrm{CO}_{2}$ in Lakes Monoun and Nyos, Cameroon, before and during controlled degassing: Geochemical Journal, v. 42, p. 93-118.

LaHusen, R.G., Swinford, K.J., Logan, Matthew, and Lisowski, Michael, 2008, Instrumentation in remote and dangerous settings; examples using data from GPS "spider" deployments during the 2004-2005 eruption of Mount St. Helens, Washington, chap. 16 of Sherrod, D.R., Scott, W.E., and Stauffer, P.H., eds., A volcano rekindled; the renewed eruption of Mount St. Helens, 2004-2006: U.S. Geological Survey Professional Paper 1750, p. 335-345, available at http://pubs.usgs.gov/pp/1750/.

Lee, Chang-Wook, Lu, Zhong, Kwoun, Oh-Ig, and Won, Joong-Sun, 2008, Deformation of the Augustine volcano, Alaska, 1992-2005, measured by ERS and ENVISAT SAR interferometry: Earth, Planets, and Space, v. 60, p. 447-452.

Lengliné, O., Marsan, D., Got, J.-L., Pinel, V., Ferrazzini, V., and Okubo, P.G., 2008, Seismicity and deformation induced by magma accumulation at three basaltic volcanoes: Journal of Geophysical Research, v. 113, B12305, doi:10.1029/2008JB005937, 12 p.

Lipman, P.W., and McIntosh, W.C., 2008, Eruptive and noneruptive calderas, northeastern San Juan Mountains, Colorado; where did the ignimbrites come from?: Geological Society of America Bulletin, v. 120, p. 771-795.

Lisowski, Michael, Dzurisin, Daniel, Denlinger, R.P., and Iwatsubo, E.Y., 2008, Analysis of GPS-measured deformation associated with the 2004-2006 dome-building eruption of Mount St. Helens, Washington, chap. 15 of Sherrod, D.R., Scott, W.E., and Stauffer, P.H., eds., A volcano rekindled; the renewed eruption of Mount St. Helens, 2004-2006: U.S. Geological Survey Professional Paper 1750, p. 301-333, available at http://pubs.usgs.gov/pp/1750/.

Lowenstern, J.B., and Hurwitz, Shaul, 2008, Monitoring a supervolcano in repose; heat and volatile flux at the Yellowstone caldera: Elements, v. 4, no. 1, p. 35-40.

Major, J.J., Kingsbury, C.G., Poland, M.P., and LaHusen, R.G., 2008, Extrusion rate of the Mount St. Helens lava dome estimated from terrestrial imagery, November 2004-December 
2005, chap. 12 of Sherrod, D.R., Scott, W.E., and Stauffer, P.H., eds., A volcano rekindled; the renewed eruption of Mount St. Helens, 2004-2006: U.S. Geological Survey Professional Paper 1750, p. 237-255, available at http://pubs.usgs.gov/pp/1750/.

Major, J.J., O’Connor, J.E., Grant, G.E., Spicer, K.R., Bragg, H.M., Rhode, Abigail, Tanner, D.Q., Anderson, C.W., and Wallick, J.R., 2008, Initial fluvial response to the removal of Oregon's Marmot Dam: Eos Transactions of the American Geophysical Union, v. 89, no. 27, p. 241-242.

Mariner, R.H., Minor, S.A., King, A.P., Boles, J.R., Kellogg, K.S., Evans, W.C., Landis, G.A., Hunt, A.G., and Till, C.B., 2008, A landslide in Tertiary marine shale with superheated fumaroles, Coast Ranges, California: Geology, v. 36, p. 959-962.

Mastin, L.G., Roeloffs, Evelyn, Beeler, N.M., and Quick, J.E., 2008, Constraints on the size, overpressure, and volatile content of the Mount St. Helens magma system from geodetic and dome-growth measurements during the 2004-2006+ eruption, chap. 22 of Sherrod, D.R., Scott, W.E., and Stauffer, P.H., eds., A volcano rekindled; the renewed eruption of Mount St. Helens, 2004-2006: U.S. Geological Survey Professional Paper 1750, p. 461-488, available at http://pubs.usgs.gov/pp/1750/.

McChesney, P.J., Couchman, M.R., Moran, S.C., Lockhart, A.B., Swinford, K.J., and LaHusen, R.G., 2008, Seismic-monitoring changes and the remote deployment of seismic stations (seismic spider) at Mount St. Helens, 2004-2005, chap. 7 of Sherrod, D.R., Scott, W.E., and Stauffer, P.H., eds., A volcano rekindled; the renewed eruption of Mount St. Helens, 20042006: U.S. Geological Survey Professional Paper 1750, p. 129-140, available at http://pubs.usgs.gov/pp/1750/.

McGee, K.A., Doukas, M.P., McGimsey, R.G., Neal, C.A., and Wessels, R.L., 2008, Atmospheric contribution of gas emissions from Augustine volcano, Alaska during the 2006 eruption: Geophysical Research Letters, v. 35, L03306, doi:10.1029/2007GL032301, 5 p.

McGimsey, R.G., Neal, C.A., Dixon, J.P., and Ushakov, Sergey, 2008, 2005 Volcanic activity in Alaska, Kamchatka, and the Kurile Islands; summary of events and response of the Alaska Volcano Observatory: U.S. Geological Survey Scientific Investigations Report 2007-5269, 91 p., available at http://pubs.usgs.gov/sir/2007/5269/.

McNutt, S.R., and Nishimura, Takeshi, 2008, Volcanic tremor during eruptions; temporal characteristics, scaling and constraints on conduit size and processes: Journal of Volcanology and Geothermal Research, v. 178, p. 10-18.

Messerich, J.A., Schilling, S.P., and Thompson, R.A., 2008, Digital elevation models of the preeruption 2000 crater and 2004-07 dome-building eruption at Mount St. Helens, Washington, USA: U.S. Geological Survey Open-File Report 2008-1169, 2 p., data files, available at http://pubs.usgs.gov/of/2008/1169/.

Moore, P.L., Iverson, N.R., and Iverson, R.M., 2008, Frictional properties of the Mount St. Helens gouge, chap. 20 of Sherrod, D.R., Scott, W.E., and Stauffer, P.H., eds., A volcano rekindled; the renewed eruption of Mount St. Helens, 2004-2006: U.S. Geological Survey Professional Paper 1750, p. 415-424, available at http://pubs.usgs.gov/pp/1750/.

Moran, S.C., Freymueller, J.T., LaHusen, R.G., McGee, K.A., Poland, M.P., Power, J.A., Schmidt, D.A., Schneider, D.J., Stephens, George, Werner, C.A., and White, R.A., 2008, Instrumentation recommendations for volcano monitoring at U.S. volcanoes under the National Volcano Early Warning System: U.S. Geological Survey Scientific Investigations Report 2008-5114, 47 p., available at http://pubs.usgs.gov/sir/2008/5114/. 
Moran, S.C., Malone, S.D., Qamar, A.I., Thelen, W.A., Wright, A.K., and Caplan-Auerbach, Jacqueline, 2008, Seismicity associated with renewed dome building at Mount St. Helens, 2004-2005, chap. 2 of Sherrod, D.R., Scott, W.E., and Stauffer, P.H., eds., A volcano rekindled; the renewed eruption of Mount St. Helens, 2004-2006: U.S. Geological Survey Professional Paper 1750, p. 27-54, available at http://pubs.usgs.gov/pp/1750/.

Moran, S.C., Matoza, R.S., Garcés, M.A., Hedlin, M.A.H., Bowers, D., Scott, W.E., Sherrod, D.R., and Vallance, J.W., 2008, Seismic and acoustic recordings of an unusually large rockfall at Mount St. Helens, Washington: Geophysical Research Letters, v. 35, L19302, doi:10.1029/2008GL035176, 6 p.

Moran, S.C., McChesney, P.J., and Lockhart, A.B., 2008, Seismicity and infrasound associated with explosions at Mount St. Helens, 2004-2005, chap. 6 of Sherrod, D.R., Scott, W.E., and Stauffer, P.H., eds., A volcano rekindled; the renewed eruption of Mount St. Helens, 20042006: U.S. Geological Survey Professional Paper 1750, p. 111-127, available at http://pubs.usgs.gov/pp/1750/.

Muffler, L.J.P. and Clynne, M.A., 2008, Field Trip \#1 Lassen Volcanic National Park and vicinity, in Greene, T.J., ed., Convergent margin tectonics in and around Chico, Northern California: Field Trip Guidebook for the National Association of Geoscience Teachers Far Western Section 2008 Fall Field Conference, p. 1-30.

Myers, Bobbie, and Driedger, Carolyn, 2008, Eruptions in the Cascade Range during the past 4,000 years: U.S. Geological Survey General Information Product 63, 1 sheet, available at http://pubs.usgs.gov/gip/63/.

Myers, Bobbie, and Driedger, Carolyn, 2008, Geologic hazards at volcanoes: U.S. Geological Survey General Information Product 64, 1 sheet, available at http://pubs.usgs.gov/gip/64/. Nakata, J.S., and Okubo, P.G., 2008, Hawaiian Volcano Observatory seismic data, January to December 2007: U.S. Geological Survey Open-File Report 2008-1261, 99 p., available at http://pubs.usgs.gov/of/2008/1261/.

Nathenson, Manuel, 2008, Publications of the Volcano Hazards Program 2006: U.S. Geological Survey Open-File Report 2008-1006, 11 p., available at http://pubs.usgs.gov/of/2008/1006/.

Neal, C.A., McGimsey, R.G., Dixon, J.P., Manevich, Alexander, and Rybin, Alexander, 2008, 2006 volcanic activity in Alaska, Kamchatka, and the Kurile Islands; summary of events and response of the Alaska Volcano Observatory: U.S. Geological Survey Scientific Investigations Report 2008-5214, 110 p., available at http://pubs.usgs.gov/sir/2008/5214/.

Neal, Christina, Rybin, Alexander, Chibisova, Marina, and Miller, Edward, 2008, Active volcanoes of the Kurile Islands; a reference guide for aviation users: U.S. Geological Survey Open-File Report 2008-1162, 10 p., available at http://pubs.usgs.gov/of/2008/1162/.

Nimz, Kathryn, Ramsey, D.W., Sherrod, D.R., and Smith, J.G., 2008, Database for the geologic map of upper Eocene to Holocene volcanic and related rocks of the Cascade Range, Oregon: U.S. Geological Survey Data Series 313, available at http://pubs.usgs.gov/ds/313/.

O'Connor, Jim, Major, Jon, and Grant, Gordon, 2008, The dams come down-Unchaining U.S. rivers: Geotimes, v. 53, no. 3, p. 22-28.

Okubo, P.G., and Wolfe, C.J., 2008, Swarms of similar long-period earthquakes in the mantle beneath Mauna Loa Volcano: Journal of Volcanology and Geothermal Research, v. 178, p. 787-794.

Ort, M.H., Elson, M.D., Anderson, K.C., Duffield, W.A., Hooten, J.A., Champion, D.E., and Waring, G., 2008, Effects of scoria-cone eruptions upon nearby human communities: Geological Society of America Bulletin, v. 120, p. 476-486. 
Orr, T.R., and Hoblitt, R.P., 2008, A versatile time-lapse camera system developed by the Hawaiian Volcano Observatory for use at Kīlauea Volcano, Hawai'i: U.S. Geological Survey Scientific Investigations Report 2008-5117, 8 p., available at http://pubs.usgs.gov/sir/2008/5117/.

Pallister, J.S., Thornber, C.R., Cashman, K.V., Clynne, M.A., Lowers, H.A., Mandeville, C.W., Brownfield, I.K., and Meeker, G.P., 2008, Petrology of the 2004-2006 Mount St. Helens lava dome-Implications for magmatic plumbing and eruption triggering, chap. 30 of Sherrod, D.R., Scott, W.E., and Stauffer, P.H., eds., A volcano rekindled; the renewed eruption of Mount St. Helens, 2004-2006: U.S. Geological Survey Professional Paper 1750, p. 647-702, available at http://pubs.usgs.gov/pp/1750/.

Pearson, S.C.P., Connor, C.B., and Sanford, W.E., 2008, Rapid response of a hydrologic system to volcanic activity; Masaya volcano, Nicaragua: Geology, v. 36, p. 951-954.

Pesicek, J.D., Thurber, C.H., DeShon, H.R., Prejean, S.G., and Zhang, Haijiang, 2008, Threedimensional $P$-wave velocity structure and precise earthquake relocation at Great Sitkin volcano, Alaska: Bulletin of the Seismological Society of America, v. 98, p. 2428-2448.

Peterson, R.A., and Dean, K.G., 2008, Forecasting exposure to volcanic ash based on ash dispersion modeling: Journal of Volcanology and Geothermal Research, v. 170, p. 230-246.

Poland, M.P., 2008, InSAR observations of deformation associated with new episodes of volcanism at Kīlauea Volcano, Hawai'i, 2007: FRINGE Workshop, Frascati, Italy, Nov. 26-30, 2007, Proceedings, Paris, France, European Space Agency, ESA SP-649, 7 p.

Poland, M.P., Dzurisin, Daniel, LaHusen, R.G., Major, J.J., Lapcewich, Dennis, Endo, E.T., Gooding, D.J., Schilling, S.P., and Janda, C.G., 2008, Remote camera observations of lava dome growth at Mount St. Helens, Washington, October 2004 to February 2006, chap. 11 of Sherrod, D.R., Scott, W.E., and Stauffer, P.H., eds., A volcano rekindled; the renewed eruption of Mount St. Helens, 2004-2006: U.S. Geological Survey Professional Paper 1750, p. 225-236, available at http://pubs.usgs.gov/pp/1750/.

Poland, M.P., and Lu, Zhong, 2008, Radar interferometry observations of surface displacements during pre- and coeruptive periods at Mount St. Helens, Washington, 1992-2005, chap. 18 of Sherrod, D.R., Scott, W.E., and Stauffer, P.H., eds., A volcano rekindled; the renewed eruption of Mount St. Helens, 2004-2006: U.S. Geological Survey Professional Paper 1750, p. 361-382, available at http://pubs.usgs.gov/pp/1750/.

Poland, M., Miklius, A., Orr, T., Sutton, J., Thornber, C., and Wilson, D., 2008, New episodes of volcanism at Kilauea Volcano, Hawaii: Eos Transactions of the American Geophysical Union, v. 89 , p. 37-38.

Poland, M.P., Moats, W.P., and Fink, J.H., 2008, A model for radial dike emplacement in composite cones based on observations from Summer Coon volcano, Colorado, USA: Bulletin of Volcanology, v. 70, p. 861-875.

Qamar, A.I., Malone, S.D., Moran, S.C., Steele, W.P., and Thelen, W.A., 2008, Near-real-time information products for Mount St. Helens-Tracking the ongoing eruption, chap. 3 of Sherrod, D.R., Scott, W.E., and Stauffer, P.H., eds., A volcano rekindled; the renewed eruption of Mount St. Helens, 2004-2006: U.S. Geological Survey Professional Paper 1750, p. 61-70, available at http://pubs.usgs.gov/pp/1750/.

Ramos H., Silvia, Macías, J.L., Espíndola, J.M., De la Cruz-Reyna, Servando, Arce, J.L., and Tilling, R.I., 2008, Commemorating the 25th anniversary of the 1982 Eruption of El Chichón Volcano, Chiapas, Mexico: International Association of Volcanology and Chemistry of the Earth's Interior News, no. 1, p. 5-7. 
Ramsey, D.W., Driedger, C.L., and Schilling, S.P., 2008, A new perspective on Mount St. Helens - Dramatic landform change and associated hazards: U.S. Geological Survey Scientific Investigations Map 3008, 1 sheet, available at http://pubs.usgs.gov/sim/3008/.

Ramsey, D.W., Dutton, D.R., and Bacon, C.R., 2008, Database for the geologic map of Mount Mazama and Crater Lake Caldera, Oregon: U.S. Geological Survey Scientific Investigations Map 2832, 1 CD-ROM, available at http://pubs.usgs.gov/sim/2832/.

Reagan, M.K., Cooper, K.M., Pallister, J.S., Thornber, C.R., and Wortel, Matthew, 2008, Timing of degassing and plagioclase growth in lavas erupted from Mount St. Helens, 2004-2005, from ${ }^{210} \mathrm{Po}-{ }^{210} \mathrm{~Pb}-{ }^{226} \mathrm{Ra}$ disequilibria, chap. 37 of Sherrod, D.R., Scott, W.E., and Stauffer, P.H., eds., A volcano rekindled; the renewed eruption of Mount St. Helens, 2004-2006: U.S. Geological Survey Professional Paper 1750, p. 847-856, available at http://pubs.usgs.gov/pp/1750/.

Reid, M.E., Iverson, R.M., Iverson, N.R., LaHusen, R.G., Brien, D.L., and Logan, Matthew, 2008, Deciphering landslide behavior using large-scale flume experiments: Proceedings of the First World Landslide Forum, Parallel Session Volume, Nov. 18-21, 2008, Tokyo, p. 497-500, available at http://www.iclhq.org/WLFweb/WLF.htm.

Restrepo, Pedro, Jorgensen, D.P., Cannon, S.H., Costa, John, Laber, Jayme, Major, Jon, Martner, Brooks, Purpura, Jim, and Werner, Kevin, 2008, Joint NOAA/NWS/USGS prototype debris flow warning system for recently burned areas in southern California: Bulletin of the American Meteorological Society, v. 89, p. 1845-1851.

Rojstaczer, S.A., Ingebritsen, S.E., and Hayba, D.O., 2008, Permeability of continental crust influenced by internal and external forcing: Geofluids, v. 8, p 128-139.

Rowe, M.C., Kent, A.J.R., and Thornber, C.R., 2008, Using amphibole phenocrysts to track vapor transfer during magma crystallization and transport; an example from Mount St. Helens, Washington, in Zellmer, G.F., Fischer, T.P., and Chen, Chang-Hwa, eds., Evolution, transfer and release of magmas and volcanic gases: Journal of Volcanology and Geothermal Research, v. 178, p. 593-607.

Rowe, M.C., Thornber, C.R., Gooding, D.J., and Pallister, J.S., 2008, Catalog of Mount St. Helens 2004-2005 tephra samples with major- and trace-element geochemistry: U.S. Geological Survey Open-File Report 2008-1131, 8 p., data table, available at http://pubs.usgs.gov/of/2008/1131/.

Rowe, M.C., Thornber, C.R., and Kent, A.J.R., 2008, Identification and evolution of the juvenile component in 2004-2005 Mount St. Helens ash, chap. 29 of Sherrod, D.R., Scott, W.E., and Stauffer, P.H., eds., A volcano rekindled; the renewed eruption of Mount St. Helens, 20042006: U.S. Geological Survey Professional Paper 1750, p. 629-646, available at http://pubs.usgs.gov/pp/1750/.

Salisbury, M.J., Bohrson, W.A., Clynne, M.A., Ramos, F.C., and Hoskin, Paul, 2008, Multiple plagioclase crystal populations identified by crystal size distribution and in situ chemical data; implications for timescales of magma chamber processes associated with the 1915 eruption of Lassen Peak, CA: Journal of Petrology, v. 49, p. 1755-1780.

Schaeffer, D.G., and Iverson, R.M., 2008, Steady and intermittent slipping in a model of landslide motion regulated by pore-pressure feedback: Society for Industrial and Applied Mathematics Journal on Applied Mathematics, v. 69, p. 769-786.

Schaefer, Janet, and Nye, Chris, 2008, Monitoring the active volcanoes of Alaska: Alaska GeoSurvey News, v. 11, no. 1, p. 1-9, available at http://www.dggs.dnr.state.ak.us.

Schaefer, J.R., Scott, W.E., Evans, W.C., Jorgenson, Janet, McGimsey, R.G., and Wang, Bronwen, 2008, The 2005 catastrophic acid crater lake drainage, lahar, and acidic aerosol 
formation at Mount Chiginagak volcano, Alaska, USA; field observations and preliminary water and vegetation chemistry results: Geochemistry, Geophysics, Geosystems, v. 9, Q07018, doi:10.1029/2007GC001900, 29 p.

Schaefer, J.R., Wallace, K.L., and Kassel, C.M., 2008, Preliminary bathymetric map of Mother Goose Lake, Alaska Peninsula: Alaska Division of Geological and Geophysical Surveys Raw Data File 2008-3, data files, available at http://wwwdggs.dnr.state.ak.us/pubs/pubs?reqtype=citation\&ID=16301.

Schiff, C.J., Kaufman, D.S., Wallace, K.L., Werner, A., Ku, T.L., and Brown, T.A., 2008, Modeled tephra ages from lake sediments, base of Redoubt Volcano, Alaska: Quaternary Geochronology, v. 3, p. 56-67.

Schilling, S.P., Doelger, S., Bacon, C.R., Mastin, L.G., Scott, K.E., and Nathenson, M., 2008, Digital data for volcano hazards in the Crater Lake region, Oregon: U.S. Geological Survey Open-File Report 2007-1223, data files, available at http://pubs.usgs.gov/of/2007/1223/.

Schilling, S.P., Doelger, S., Hoblitt, R.P., Walder, J.S., Driedger, C.L., Scott, K.M., Pringle, P.T., and Vallance, J.W., 2008, Digital data for volcano hazards from Mount Rainier, Washington, Revised 1998: U.S. Geological Survey Open-File Report 2007-1220, data files, available at http://pubs.usgs.gov/of/2007/1220/.

Schilling, S.P., Doelger, S., Scott, W.E., and Iverson, R.M., 2008, Digital data for volcano hazards of the Three Sisters region, Oregon: U.S. Geological Survey Open-File Report 20071221, data files, available at http://pubs.usgs.gov/of/2007/1221/.

Schilling, S.P., Doelger, S., Scott, W.E., Pierson, T.C., Costa, J.E., Gardner, C.A., Vallance, J.W., and Major, J.J., 2008, Digital data for volcano hazards of the Mount Hood region, Oregon: U.S. Geological Survey Open-File Report 2007-1222, data files, available at http://pubs.usgs.gov/of/2007/1222/.

Schilling, S.P., Doelger, S., Sherrod, D.R., Mastin, L.G., and Scott, W.E., 2008, Digital data for volcano hazards at Newberry Volcano, Oregon: U.S. Geological Survey Open-File Report 2007-1225, data files, available at http://pubs.usgs.gov/of/2007/1225/.

Schilling, S.P., Doelger, S., Walder, J.S., Gardner, C.A., Conrey, R.M., and Fisher, B.J., 2008, Digital data for volcano hazards in the Mount Jefferson region, Oregon: U.S. Geological Survey Open-File Report 2007-1224, data files, available at http://pubs.usgs.gov/of/2007/1224/.

Schilling, S.P., Thompson, R.A., Messerich, J.A., and Iwatsubo, E.Y., 2008, Use of digital aerophotogrammetry to determine rates of lava dome growth, Mount St. Helens, Washington, 2004-2005, chap. 8 of Sherrod, D.R., Scott, W.E., and Stauffer, P.H., eds., A volcano rekindled; the renewed eruption of Mount St. Helens, 2004-2006: U.S. Geological Survey Professional Paper 1750, p. 145-167, available at http://pubs.usgs.gov/pp/1750/.

Schneider, D.J., Vallance, J.W., Wessels, R.L., Logan, Matthew, and Ramsey, M.S., 2008, Use of thermal infrared imaging for monitoring renewed dome growth at Mount St. Helens, 2004, chap. 17 of Sherrod, D.R., Scott, W.E., and Stauffer, P.H., eds., A volcano rekindled; the renewed eruption of Mount St. Helens, 2004-2006: U.S. Geological Survey Professional Paper 1750, p. 347-359, available at http://pubs.usgs.gov/pp/1750/.

Scott, W.E., Sherrod, D.R., and Gardner, C.A., 2008, Overview of the 2004 to 2006, and continuing, eruption of Mount St. Helens, Washington, chap. 1 of Sherrod, D.R., Scott, W.E., and Stauffer, P.H., eds., A volcano rekindled; the renewed eruption of Mount St. Helens, 20042006: U.S. Geological Survey Professional Paper 1750, p. 3-22, available at http://pubs.usgs.gov/pp/1750/. 
Sherrod, D.R., Scott, W.E., and Stauffer, P.H., eds., 2008, A volcano rekindled; the renewed eruption of Mount St. Helens, 2004-2006: U.S. Geological Survey Professional Paper 1750, 856 p., 1 DVD-ROM, available at http://pubs.usgs.gov/pp/1750/.

Sherrod, D.R., Vallance, J.W., Tapia Espinosa, Arkin, and McGeehin, J.P., 2008, Volcán Barú-Eruptive history and volcano-hazards assessment: U.S. Geological Survey Open-File Report 2007-1401, 33 p., 1 plate, scale 1:100,000, available at http://pubs.usgs.gov/of/2007/1401/.

Sine, C.R., Wilson, D., Gao, W., Grand, S.P., Aster, R., Ni, J., and Baldridge, W.S., 2008, Mantle structure beneath the western edge of the Colorado Plateau: Geophysical Research Letters, v. 35, L10303, doi:10.1029/2008GL033391, 5 p.

Spinetti, Claudio, Carrère, Véronique, Buongiorno, M.F., Sutton, A.J., and Elias, Tamar, 2008, Carbon dioxide of Pu 'u 'O'o volcanic plume at Kilauea retrieved by AVIRIS hyperspectral data: Remote Sensing of Environment, v. 112, p. 3192-3199.

Streck, M.J., Broderick, C.A., Thornber, C.R., Clynne, M.A., and Pallister, J.S., 2008, Plagioclase populations and zoning in dacite of the 2004-2005 Mount St. Helens eruption; constraints for magma origin and dynamics, chap. 34 of Sherrod, D.R., Scott, W.E., and Stauffer, P.H., eds., A volcano rekindled; the renewed eruption of Mount St. Helens, 20042006: U.S. Geological Survey Professional Paper 1750, p. 791-808, available at http://pubs.usgs.gov/pp/1750/.

Swanson, D.A., 2008, Hawaiian oral tradition describes 400 years of volcanic activity at Kīlauea, in Cashman, K.V., and Giordano, G., eds., Volcanoes and human history: Journal of Volcanology and Geothermal Research, v. 176, p. 427-431.

Teng, F.-Z., Dauphas, Nicolas, and Helz, R.T., 2008, Iron isotope fractionation during magmatic differentiation in Kilauea Iki lava lake: Science, v. 320, p. 1620-1622.

Thelen, W.A., Crosson, R.S., and Creager, K.C., 2008, Absolute and relative locations of earthquakes at Mount St. Helens, Washington, using continuous data; implications for magmatic processes, chap. 4 of Sherrod, D.R., Scott, W.E., and Stauffer, P.H., eds., A volcano rekindled; the renewed eruption of Mount St. Helens, 2004-2006: U.S. Geological Survey Professional Paper 1750, p. 71-95, available at http://pubs.usgs.gov/pp/1750/.

Thornber, C.R., Pallister, J.S., Lowers, H.A., Rowe, M.C., Mandeville, C.W., and Meeker, G.P., 2008, Chemistry, mineralogy, and petrology of amphibole in Mount St. Helens 2004-2006 dacite, chap. 32 of Sherrod, D.R., Scott, W.E., and Stauffer, P.H., eds., A volcano rekindled; the renewed eruption of Mount St. Helens, 2004-2006: U.S. Geological Survey Professional Paper 1750, p. 727-754, available at http://pubs.usgs.gov/pp/1750/.

Thornber, C.R., Pallister, J.S., Rowe, M.C., McConnell, Siobhan, Herriott, T.M., Eckberg, Alison, Stokes, W.C., Johnson Cornelius, Diane, Conrey, R.M., Hannah, Tammy, Taggart, J.E., Jr., Adams, Monique, Lamothe, P.J., Budahn J.R., and Knaack, C.M., 2008, Catalog of Mount St. Helens 2004-2007 dome samples with major- and trace-element chemistry: U.S. Geological Survey Open-File Report 2008-1130, 9 p., data table, available at http://pubs.usgs.gov/of/2008/1130/.

Tilling, R.I., 2008, The critical role of volcano monitoring in risk reduction, in Fabian, P., and Lagos, P., eds., The role of geophysics in natural disaster prevention, 2nd EGU Alexander von Humboldt Conference: Advances in Geosciences, v. 14, p. 3-11.

Tilman, M.R., 2008, An investigation of symplectite-rimmed olivine and magmatic processes during the 2006 eruption of Augustine Volcano, Alaska: University of Alaska Fairbanks M.S. thesis, $166 \mathrm{p}$. 
University of Alaska, 2008, 20th anniversary of the Alaska Volcano Observatory: University of Alaska Geophysical Institute, 6 p., available at http://www.avo.alaska.edu/pdfs/cit4450.pdf.

Vallance, J.W., Schneider, D.J., and Schilling, S.P., 2008, Growth of the 2004-2006 lava-dome complex at Mount St. Helens, Washington, chap. 9 of Sherrod, D.R., Scott, W.E., and Stauffer, P.H., eds., A volcano rekindled; the renewed eruption of Mount St. Helens, 2004-2006: U.S. Geological Survey Professional Paper 1750, p. 169-207, available at http://pubs.usgs.gov/pp/1750/.

Waite, G.P., Chouet, B.A., and Dawson, P.B., 2008, Eruption dynamics at Mount St. Helens imaged from broadband seismic waveforms; interaction of the shallow magmatic and hydrothermal systems: Journal of Geophysical Research, v. 113, B02305, doi:10.1029/2007JB005259, 22 p.

Walder, J.S., Schilling, S.P., Vallance, J.W., and LaHusen, R.G., 2008, Effects of lava-dome growth on the Crater Glacier of Mount St. Helens, Washington, chap. 13 of Sherrod, D.R., Scott, W.E., and Stauffer, P.H., eds., A volcano rekindled; the renewed eruption of Mount St. Helens, 2004-2006: U.S. Geological Survey Professional Paper 1750, p. 257-276, available at http://pubs.usgs.gov/pp/1750/.

Wang, Xinling, Ni, J.F., Aster, Richard, Sandvol, Eric, Wilson, David, Sine, Christopher, Grand, S.P., and Baldridge, W.S., 2008, Shear-wave splitting and mantle flow beneath the Colorado Plateau and its boundary with the Great Basin: Bulletin of the Seismological Society of America, v. 98, p. 2526-2532.

Waythomas, C.F., Prejean, S.G., and McNutt, S.R., 2008, Alaska's Pavlof Volcano ends 11-year repose: Eos Transactions of the American Geophysical Union, v. 89, p. 209, 211.

Werner, C., Hurst, T., Scott, B., Sherburn, S., Christenson, B.W., Britten, K., Cole-Baker, J., and Mullan, B., 2008, Variability of passive gas emissions, seismicity, and deformation during crater lake growth at White Island Volcano, New Zealand, 2002-2006: Journal of Geophysical Research, v. 113, B01204, doi:10.1029/2007JB005094, 15 p.

Werner, C., Hurwitz, S., Evans, W.C., Lowenstern, J.B., Bergfeld, D., Heasler, H., Jaworowski, C., and Hunt, A., 2008, Volatile emissions and gas geochemistry of Hot Spring Basin, Yellowstone National Park, USA: Journal of Volcanology and Geothermal Research, v. 178, p. 751-762.

Williams-Jones, Glyn, Rymer, Hazel, Mauri, Guillaume, Gottsmann, Joachim, Poland, Michael, and Carbone, Daniele, 2008, Towards continuous 4D microgravity monitoring of volcanoes: Geophysics, v. 73, no. 6, p. WA19-WA28.

Wilson, David, Elias, Tamar, Orr, Tim, Patrick, Matt, Sutton, Jeff, and Swanson, Don, 2008, Small explosion from new vent at Kilauea's summit: Eos Transactions of the American Geophysical Union, v. 89, p. 203.

Wright, T.L., and Klein, F.W., 2008, Dynamics of magma supply to Kīlauea volcano, Hawai' $i$ : integrating seismic, geodetic and eruption data, in Annen, C., and Zellmer, G.F., eds., Dynamics of crustal magma transfer, storage and differentiation: Geological Society of London Special Publication 304, p. 83-116.

Zimmerman, C.E., Neal, C.A., and Haeussler, P.J., 2008, Natural hazards, fish habitat, and fishing communities in Alaska: American Fisheries Society Symposium, v. 64, p. 375-388. 